\title{
MANUSIA, AKAL DAN KEBAHAGIAAN (Studi Analisis Komparatif antara Alquran dengan Filsafat Islam)
}

\author{
Oleh \\ Mohamad Nursalim Azmi \\ Dosen, Sekolah Tinggi Ilmu Al-Qur'an (STIQ) Amuntai, \\ Kalimantan Selatan \\ Muhammad Zulkifli \\ Dosen, Sekolah Tinggi Ilmu Al-Qur'an (STIQ) Amuntai, \\ Kalimantan Selatan
}

\begin{abstract}
Abstrak
Manusia adalah makhluk yang diciptakan Allah SWT dari intisari tanah yang dijadikan nuthfah dan disimpan ditempat yang kokoh, kemudian nuthfah itu dijadikan darah beku, dari darah beku itu dijadikan mudgah, mudgah dijadikan tulang, dari tulang dibalut dengan daging yang kemudian dijadikan Allah SWT. Akal adalah Setiap orang menyadari bahwa ia mempunyai akal, akal berpusat di otak, hasil rumusan akal (pikiran) dapat dirasakan dan diyakini kebenarannya, hasil kerja akal dapat memberikan rasa kenikmatan tersendiri pada diri individu dan Kebahagiaan adalah seseorang mencapai sesuatu nikmat, nikmat itu adalah sesungguhnya kebahagiaan adalah tujuan hidup manusia, bahagia di dunia dan bahagia di akhirat.

Metode penelitian dalam jurnal ini menggunakan jenis penelitian kualitatif dengan pendekatan literatur. Pengumpulan data dilakukan dengan pencarian sumber-sumber buku referensi terkait. Setelah data diperoleh kemudian data di analisis dan beberapa tambahan dari peneliti.

Dalam penelitian ini, peneliti menemukan beberapa hasil dan kesimpulan dalam bahasan Manusia, akal dan kebahagiaan, yaitu: Pertama, Berbagai teori tentang asal usul manusia terbantahkan dengan dalil Alquran. Kedua, Proses penciptaan manusia sangat jelas diterangkan dalam Alquran yang saat itu belum ada penelitian biologi. Ketiga, Akal merupakan hal pembeda dengan makhluk lainnya. Keempat, Agama merupakan jalan terbaik untuk mendapatkan kebahagiaan.
\end{abstract}

Kata Kunci : Manusia, akal, kebahagiaan, nuthfah, dan mudgah. 
Mohamad Nursalim Azmi dan Muhammad Zulkifli: Manusia, Akal dan Kebahagiaan (Studi Analisis Komparatif antara Alquran dengan Filsafat)

\section{A. Pendahuluan}

Manusia adalah makhluk Allah, yaitu makhluk hidup yang sempurna karena memiliki nafsu dan akal, serta berbudi pekerti ${ }^{1}$ maka disebut juga makhluk sosial yaitu manusia tidak dapat hidup sendiri, karena memerlukan orang lain dalam masyarakat untuk memenuhi kebutuhan hidupnya. Hal ini terjadi karena secara sosiologis membutuhkan manusia yang lain untuk hidup berkelompok ${ }^{2}$. Sehingga manusia dan alam semesta bukan terjadi dengan sendirinya, tetapi dijadikan oleh Allah SWT, Tuhan Yang Maha Pencipta dan Yang Maha Kuasa.

Allah SWT berfirman dalam Surat Al-Hujuraat ayat 13 yang artinya:

Hai manusia, sesungguhnya Kami menciptakan kamu dari seorang laki-laki dan seorang perempuan dan menjadikan kamu berbangsa-bangsa dan bersuku-suku supaya kamu saling kenalmengenal. Sesungguhnya orang yang paling mulia diantara kamu disisi Allah ialah orang yang paling takwa diantara kamu. Sesungguhnya Allah Maha Mengetahui lagi Maha Mengenal.

Dalam Alquran banyak ditemukan gambaran yang membicarakan tentang manusia dan makna filosofis dari penciptaannya. Manusia merupakan makhluk-Nya paling sempurna dan sebaik-baik ciptaan yang dilengkapi dengan akal pikiran. Dalam hal ini Ibnu 'Arabi melukiskan filosofis manusia dengan mengatakan bahwa "tak ada makhluk Allah yang lebih bagus daripada manusia, yang memiliki daya hidup,

\footnotetext{
${ }^{1}$ Tim Redaksi, Kamus Besar Bahasa Indonesia, Edisi Kedua (Jakarta : Balai Pustaka, 1991), h. . 629.

${ }^{2}$ Agung Tri Haryanto dan Eko Sujatmiko, Kamus Sosiologi (Surakarta: Aksarra Sinergi Media, 2012), h. 137.
}

Jurnal Ilmiah Al QALAM, Vol. 12, No. 2, Juli-Desember 2018 
Mohamad Nursalim Azmi dan Muhammad Zulkifli: Manusia, Akal dan Kebahagiaan (Studi Analisis Komparatif antara Alquran dengan Filsafat)

mengetahui, berkehendak, berbicara, melihat, mendengar, berpikir dan memutuskan". Manusia adalah makhluk mikro kosmos yang sangat penting, karena dilengkapi dengan semua pembawaan dan syarat-syarat yang diperlukan bagi pengembangan tugas dan fungsinya sebagai makhluk Allah SWT, sebagai 'Abd (pengabdi Allah) dan sebagai khalifah di muka bumi ini ${ }^{3}$.

Untuk menjalankan tugas dan fungsinya itu Allah SWT telah menganugerahkan kepada manusia berbagai potensi, diantara potensi yang teramat berharga adalah akal. Akal itulah yang membedakan antara manusia dengan makhluk yang lain, dengan akal itulah manusia mampu menghadapi kehidupannya, yang pada akhirnya mampu meraih keberhasilan hidup atau kebahagiaan.

\section{B. Pandangan Filsafat Islam Terhadap Manusia, Akal dan Kebahagian}

\section{a. Pandangan Filsafat Islam Terhadap Manusia}

Berbagai jenis teori tentang asal-usul manusia telah banyak kita ketahui hingga saat ini, bahkan berbagai materi pelajaran anak sekolah pun juga menggunakan berbagai teori-teori dari mana manusia berasal. Salah satu teori ilmu pengetahuan sekuler tentang penciptaan manusia adalah Teori Evolusi Darwin.

Teori Darwin dalam judul bukunya On The Origin Of Species yang terbit di Inggris tahun 1959 M. Isi Teori Darwin tersebut adalah :

1. Darwin berusaha mengetengahkan sebuah teori mengenai asal-usul species melalui seleksi alam atau bertahannya ras-ras yang

${ }^{3}$ Ismail Raji 'Al-Faruq, Islam dan Kebudayaan ( Bandung: Mizan, 1984), h. 37.

Jurnal Ilmiah Al QALAM, Vol. 12, No. 2, Juli-Desember 2018 
Mohamad Nursalim Azmi dan Muhammad Zulkifli: Manusia, Akal dan Kebahagiaan (Studi Analisis Komparatif antara Alquran dengan Filsafat)

beruntung dalam perjuangan untuk mempertahankan penghidupannya.

2. Darwin berusaha menenukan mekanisme, yang melalui mekanisme itu satu species dapat berubah menjadi species lain.

Oleh karena itu pengikut-pengikut Darwin yang paling ekstrem menjadikan Darwinisme sebagai acuan bahwa manusia adalah keturunan $k$ era $^{4}$. Atas Darwinisme tersebut P.P.Grasse dalam judul bukunya L'Homme Accusatian (Manusia sebagai Tertuduh), berusaha mencari bukti kebenaran Darwinisme dan pengikut-pengikutnya yang paling ekstrem, secara kritis, melalui penelitian secara teliti dan mengumpulkan pendapat para ahlinya tentang perbedaan siamang dengan gorilla, dan perbedaan gorilla dengan manusia. Baik secara fisiologi, anatomis maupun biologis, akhirnya P.P.Grasse menyimpulkan bahwa antara manusia dan kera berbeda, dengan kata lain tidak terbukti ${ }^{5}$.

Berdasarkan penelitian P.P.Grasse tersebut diatas, ternyata tidak terbukti bahwa manusia keturunan kera seperti ungkapan menurut Darwinisme. Akhirnya Alquranlah yang mampu memberikan jawaban atas pertanyan berikut:

Dari mana manusia berasal?

Bagaimana manusia diciptakan?

Dalam hal ini Alquran semenjak 14 abad yang lalu telah menegaskan dengan memberikan jawaban bahwa manusia bukan keturunan dari kera, melainkan manusia pertama adalah Nabi Adam as yang diciptakan oleh Allah SWT dari tanah. Allah SWT menciptakan

\footnotetext{
${ }^{4}$ Mauries Bucaille, Asul-usul Manusia Menurut Bibel, al-Qur'an dan Sains (Bandung: Mizan, Bandung, 1989), h. 34.

${ }^{5}$ P.P.Grasse, L'Homme Accusation (Manusia sebagai Tertuduh), dikutib Mauries Bucaille, dalam asal-usul Manusia menurut Bibel, al-Qur'an dan Sains (Bandung: Mizan,1989), h. 47.
}

Jurnal Ilmiah Al QALAM, Vol. 12, No. 2, Juli-Desember 2018 
Mohamad Nursalim Azmi dan Muhammad Zulkifli: Manusia, Akal dan Kebahagiaan (Studi Analisis Komparatif antara Alquran dengan Filsafat)

manusia yang terdiri materi dan roh, melalui tahapan-tahapan, dari turap menjadi tanah, kemudian menjadi lumpur hitam yang diberi bentuk dan kemudian menjadi tanah kering seperti tembikar, dan setelah disempurnakan bentuknya, Allah SWT meniupkan roh (ciptaan-Nya) maka terjadilah Nabi Adam as ${ }^{6}$. Inilah pandanga filsafat Islam terdahap manusia.

Firman Allah SWT dalam surat Al-Hijr ayat 28-29 :

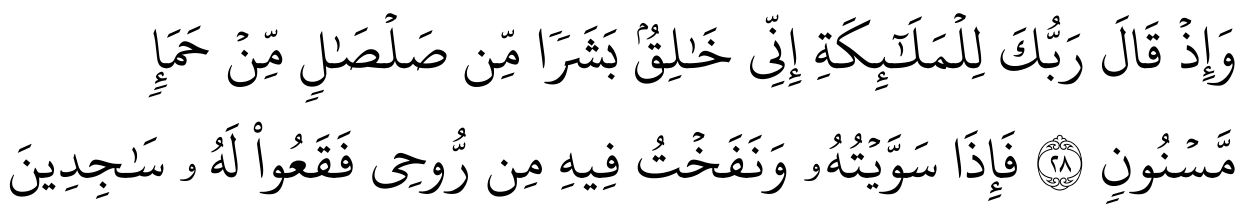

Artinya : Dan (ingatlah), ketika Tuhanmu berfirman kepada Para Malaikat: "Sesungguhnya aku akan menciptakan seorang manusia dari tanah liat kering (yang berasal) dari lumpur hitam yang diberi bentuk (28), Maka apabila aku telah menyempurnakan kejadiannya, dan telah meniup kan kedalamnya ruh (ciptaan)-Ku, Maka tunduklah kamu kepadanya dengan bersujud (29).

Konsep manusia dalam Islam juga dapat diambil darin ayat Alquran surat al-Mukminun ayat 12-16 :

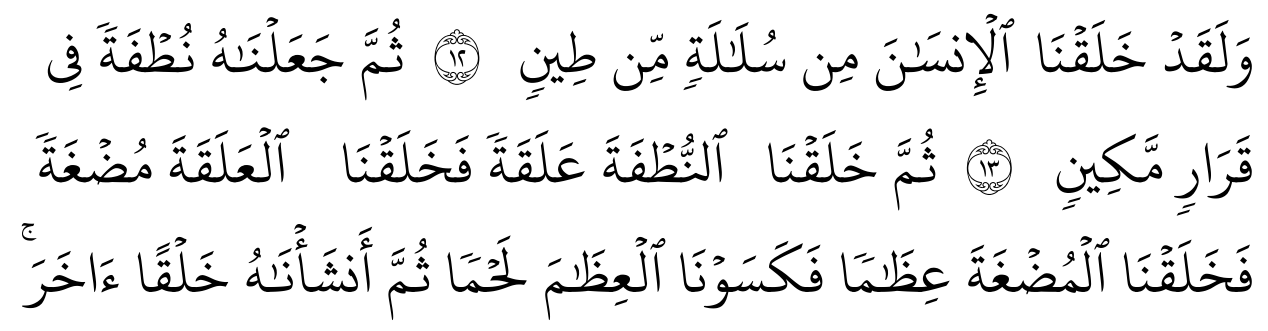

${ }^{6}$ Rohiman Notowidagdo, Ilmu Budaya Dasar Al-Qur'an dan Hadits, PT. Raja Grafindo Persada, Jakarta, 1996, hal. 17.

Jurnal Ilmiah Al QALAM, Vol. 12, No. 2, Juli-Desember 2018 
Mohamad Nursalim Azmi dan Muhammad Zulkifli: Manusia, Akal dan Kebahagiaan (Studi Analisis Komparatif antara Alquran dengan Filsafat)

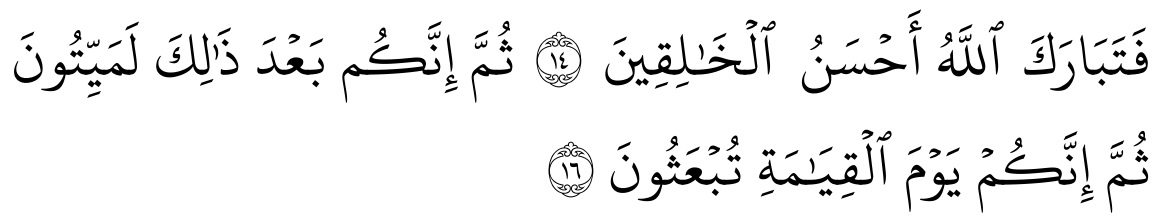

Artinya : Dan Sesungguhnya Kami telah menciptakan manusia dari suatu saripati (berasal) dari tanah (12), Kemudian Kami jadikan saripati itu air mani (yang disimpan) dalam tempat yang kokoh (rahim) (13),

Kemudian air mani itu Kami jadikan segumpal darah, lalu segumpal darah itu Kami jadikan segumpal daging, dan segumpal daging itu Kami jadikan tulang belulang, lalu tulang belulang itu Kami bungkus dengan daging. kemudian Kami jadikan Dia makhluk yang (berbentuk) lain. Maka Maha sucilah Allah, Pencipta yang paling baik (14), Kemudian, sesudah itu, Sesungguhnya kamu sekalian benar-benar akan mati (15), Kemudian, Sesungguhnya kamu sekalian akan dibangkitkan (dari kuburmu) di hari kiamat (16).

Bahwa manusia diciptakan Allah SWT dari intisari tanah yang dijadikan nuthfah dan disimpan ditempat yang kokoh, kemudian nuthfah itu dijadikan darah beku, dari darah beku itu dijadikan mudgah, mudgah dijadikan tulang, dari tulang dibalut dengan daging yang kemudian dijadikan Allah SWT makhluk lain.

Dalam surat al-Sajadah ayat 7-9 Allah SWT juga menjelaskan yang berbunyi :

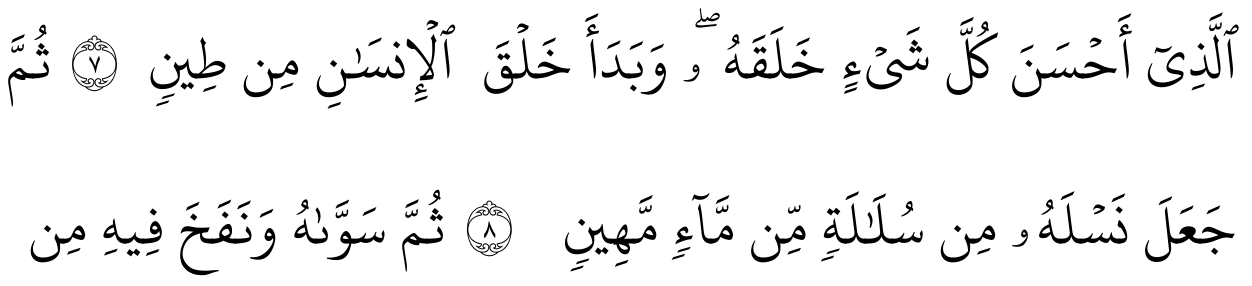


Mohamad Nursalim Azmi dan Muhammad Zulkifli: Manusia, Akal dan Kebahagiaan (Studi Analisis Komparatif antara Alquran dengan Filsafat)

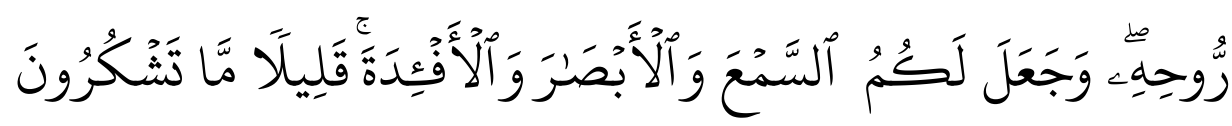

Artinya : Yang membuat segala sesuatu yang Dia ciptakan sebaikbaiknya dan yang memulai penciptaan manusia dari tanah (7), Kemudian Dia menjadikan keturunannya dari saripati air yang hina (8), Kemudian Dia menyempurnakan dan meniupkan ke dalamnya roh (ciptaan)-Nya dan Dia menjadikan bagi kamu pendengaran, penglihatan dan hati; (tetapi) kamu sedikit sekali bersyukur (9).

Dalam surat ini Allah SWT telah menjelaskan bahwa setelah kejadian manusia dalam kandungan mengambil bentuk, ditiupkan Allah SWT ke dalamnya Roh dan dijadikannya pendengaran, penglihatan dan perasaan.

Dari ayat tersebut diatas jelas kelihatan bahwa manusia tersusun dari dua unsur, materi dan imateri, jasmani dan rohani. Tubuh manusia berasal dari tanah dan roh atau jiwa berasal dari substansi imateri di alam gaib. Tubuh pada akhirnya akan kembali menjadi tanah dan roh atu jiwa akan pulang ke alam gaib.

Tubuh mempunyai daya fisik jasmani yaitu mendengar, melihat, merasa, meraba, mencium dan daya gerak, baik ditempat seperti menggerakkan tangan, kepala, kaki, mata dan sebagainya, maupun pindah tempat seperti pindah tempat duduk, ke luar rumah dan sebagainya. 
Mohamad Nursalim Azmi dan Muhammad Zulkifli: Manusia, Akal dan Kebahagiaan (Studi Analisis Komparatif antara Alquran dengan Filsafat)

Dalam pada itu roh atau jiwa yang juga disebut al nafs mempunyai dua daya, daya pikir yang disebut akal yang berpusat di kepala dan daya rasa yang berpusat di kalbu yang terletak di dada ${ }^{7}$.

Dengan penciptanan seperti itu, manusia dibedakan dari seluruh makhluk lainnya. Ia serupa dengan hewan dalam sebagian besar karakteristik fisik, dorongan emosi untuk memperthankan diri serta kemampuan untuk memahami dan belajar. Namun ia berbeda dengan hewan dari karakteristik rohnya yang membuatnya cenderung mencari Allah SWT dan menyembah-Nya dan rindu akan keutamaan idealisme yang mengantarkannya pada peringkat tertinggi dari kesempurnaan manusiawi $^{8}$, dan inilah kiranya pandangan filsafat Islam terhadap manusia selanjutnya.

Dra. Zuhairini dalam judul bukunya Filsafat pendidikan Islam mengungkapkan bahwa manusia terdiri dari dua substansi yaitu materi yang berasal dari bumi dan roh berasal dari Tuhan. Maka pandang Islam manusia adalah roh, sedangkan jasadnya adalah alat yang dipergunakan oleh roh untuk menjalankan kehidupan material di alam yang material bersifat sekunder dan roh adalah primer, karena roh saja tanpa jasad yang material, tidak dapat dinamakan manusia. Malaikat adalah makhluk rohaniah (bersifat roh semata) tidak memiliki unsur jasad yang material. Tetapi sebaliknya unsur jasad yang material saja tanpa roh, maka juga bukan manusia namanya. Hewan adalah makhluk yang bersifat jasad material yang hidup. Manusia tanpa roh, tidak lebih dari hewan? ${ }^{9}$.

\footnotetext{
${ }^{7}$ Rohiman Notowidagdo, Ilmu Budaya Dasar ..., h. 17.

${ }^{8}$ M.Ustman Najati, Al-Qur'an dan Ilmu Jiwa (Bandung: Pustaka, Bandung, 1985), h. 244.

${ }^{9}$ Zuhairini dkk, Filsafat Pendidikan Islam (Jakarta: Bumi Aksara, 1992), h. 77.
}

Jurnal Ilmiah Al QALAM, Vol. 12, No. 2, Juli-Desember 2018 
Mohamad Nursalim Azmi dan Muhammad Zulkifli: Manusia, Akal dan Kebahagiaan (Studi Analisis Komparatif antara Alquran dengan Filsafat)

Harun Nasution mengemukakan, secara biologis manusia adalah makhluk yang paling sempurna. Ia merupakan hasil akhir dari proses penciptaan evolusi alam semesta. Manusia adalah makhluk dua dimensional. Disatu sisi ia terbuat dari tanah (thin) yang menjadikannya sebagai makhluk fisikal sedangkan disisi yang lain manusia juga merupakan makhluk spiritual karena ditiupkan ke dalamnya roh dari Tuhan. Dengan demikian manusia menduduki posisi yang unik antara alam semesta dan Tuhan, yang memungkinkan berkomunikasi dengan keduanya.

Sebagai makhluk fisik manusia adalah makhluk yang paling maju dan sempurna secara biologis, dan merupakan puncak evolusi alam. Sebagai makhluk yang paling maju secara fisik dan paling rumit dalam strukturnya manusia mengandung ke semua unsur yang ada dalam kosmos. Mulai dari unsur yang ada dalam dunia mineral (batu-batuan, logam, dsb), dunia tumbuhan dengan kemampuan untuk tumbuhdan berkembangbiak, sampai yang ada pada dunia binatang dengan kemampuan untuk bergerak dengan bebas dan untuk memiliki jiwa rasional yang hanya dimiliki oleh bangsa manusia. Jiwa rasional itu memungkinkan manusia mampu untuk mengambil premis-premis rasional dan berguna untuk membimbing, mengatur dan menguasai dayadaya dan jiwa-jiwa yang rendah. Dengan demikian maka manusia merupakan inti dari alam semesta, dan tidak heran kalau para bijaksanawan penyebutnya sebagai mikrokosmos yang mengandung semua unsur yang terdapat dalam mikrokosmos ${ }^{10}$.

\footnotetext{
${ }^{10}$ Abdul Halim (editor), Teologi Islam Rasional (Jakarta: Ciputat Press, 2002), h. 104 .
}

Jurnal Ilmiah Al QALAM, Vol. 12, No. 2, Juli-Desember 2018 
Mohamad Nursalim Azmi dan Muhammad Zulkifli: Manusia, Akal dan Kebahagiaan (Studi Analisis Komparatif antara Alquran dengan Filsafat)

H.Samsul Nizar juga mengatakan, bahwa Alquran telah menunjukkan makna manusia itu diantaranya sebagai al-Insan. Kata alInsan digunakan Alquran untuk menunjukkan totalitas manusia sebagai makhluk jasmani dan rohani. Harmonisasi kedua aspek tersebut dengan berbagai potensi yang dimilikinya, mengantarkan manusia sebagai makhluk Allah SWT yang unik dan istimewa, sempurna dan memiliki diferinsiasi individual antara satu dengan yang lain, dan sebagai makhluk dinamis, sehingga mampu menyandang predikat khalifah Allah SWT di muka bumi ini ${ }^{11}$.

Kemudian Syahidin dalam judul bukunya Metode Pendidikan Qur'an Teori dan Aplikasi, melihat pandangan filsafat Islam tentang manusia lebih dari apa yang tertera di atas. Pencarian pandangan manusia katanya tidak bisa hanya terpaku pada pemikiran tentang sesuatu yang menjadi unsur pokok yang menentukan dirinya, sebab pandangan yang hanya melacak unsur pokok pada asal mula adanya manusia dapat mengakibatkan terabaikannya aspek realita dan dinamika kehidupannya. Padahal dalam Alquran Allah SWT juga mengisyaratkan bahwa untuk melihat padangan manusia dapat dilihat dari amal perbuatan dan pekerjaannya, terdapat pada Alquran surat at-Taubah ayat 105 yang berbunyi :

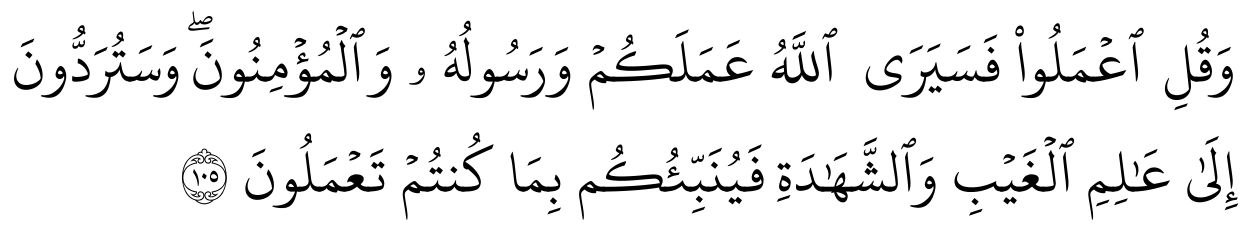

Artinya : Dan Katakanlah: "Bekerjalah kamu, Maka Allah dan RasulNya serta orang-orang mukmin akan melihat pekerjaanmu itu, dan kamu

${ }^{11}$ Samsul Nizar, Filsafat Pendidikan Islam (Jakarta: Ciputat Press, 2002), h.5.

Jurnal Ilmiah Al QALAM, Vol. 12, No. 2, Juli-Desember 2018 
Mohamad Nursalim Azmi dan Muhammad Zulkifli: Manusia, Akal dan Kebahagiaan (Studi Analisis Komparatif antara Alquran dengan Filsafat)

akan dikembalikan kepada (Allah) yang mengetahui akan yang ghaib dan yang nyata, lalu diberitakan-Nya kepada kamu apa yang telah kamu kerjakan.

Ayat di atas secara tegas menyatakan bahwa apa yang dikerjakan manusia adalah yang menentukan eksistensinya, baik dihadapan Tuhan maupun Rasul-Nya serta dihadapan orang-orang yang beriman. Tindakan atau pekerjaan manusia merupakan perwujudan sepenuhnya dari dirinya, mewakili citra dirinya dan sebagai ukuran untuk menilai dirinya.

Ayat di atas itu juga menegaskan bahwa amal perbuatan seseorang/manusia dapat menentukan arti hidupnya, baik di hadapan Tuhan maupun sesama manusia. Pada amal perbuatan manusia terletak pandangan manusia yang sebenarnya, bukan hanya pada unsur pokok yang membentuk dirinya yakni dimensi jasmani dan roh. Namun amal dalam pandangan Alquran mempunyai arti yang amat luas, yang menyangkut berbagai aspek kehidupan manusia di dunia ini dan bukan semata-mata kegiatan peribadatan formal seperti yang diatur dalam kehidupan keagamaan. Dalam hubungan ini amal merupakan penjelmaan kesatuan diri (nafs), kesatuan jasmani dan roh yang menjelma dalam perbuatan nyata, yaitu perbuatan nyata dari manusia sebagai hamba Allah SWT dan bertugas sebagai khalifah Allah SWT di muka bumi.

Maka Syahidin menyimpulkan bahwa pandangan filsafat Islam bahwa manusia dalam Alquran adalah amal dan karyanya, dan dalam karya atau perbuatan tersebut terjelma nilai-nilai kemanusiaan. Manusia menampakkan dirinya secara nyata dalam karya dan perbuatannya sebagai wujud perbuatan-perbuatan yang disadari. Karyanya merupakan totalitas diri, antara jasmani dan rohani manusia menyatu secara nyata 
Mohamad Nursalim Azmi dan Muhammad Zulkifli: Manusia, Akal dan Kebahagiaan (Studi Analisis Komparatif antara Alquran dengan Filsafat)

dan dinamis. Melalui karyanya, kualitas kemanusiaan setiap individu akan dilihat dan dinilai oleh Allah SWT. ${ }^{12}$

\section{b. Pandangan Filsafat Islam Terhadap Akal}

Dalam diri manusia terdapat sesuatu yang tidak ternilai harganya, anugerah yang maha besar dari Tuhan, tidak diberikan kepada makhluk yang lainnya, yaitu "akal". Sekiranya manusia tidak diberikan akal, niscaya keadaan dan perbuatannya akan sama saja dengan hewan.

Dengan adanya akal, segala anggota manusia, gerak-diamnya semua berarti dan berharga. Juga akal itu dapat digunakan untuk berpikir dan memperhatikan segala benda dan barang yang ada di alam ini, sehingga benda-benda dan barang-barang yang halus serta tersembunyi, dapat dipikirkan guna dan manfaatnya. Al hasil bila akal digunakan dengan semestinya, niscaya tidak ada benda-benda dan barang-barang di dunia ini yang sia-sia bagi manusia ${ }^{13}$.

Yang membedakan manusia dengan jenis makhluk ciptaan Allah lainnya adalah terletak pada akalnya, manusia memiliki akal dan budi yang dengan potensi ini manusia dapat berpikir dan berbuat penuh melebihi dari kemampuan binatang, manusia dapat memahami hal abstrak, dan mengabstrakkan hal-hal yang konkret.

Dengan akal ia dapat menghubungkan sebab akibat dan dapat mengerti lambang-lambang bahasa, dan dengan akal manusia melahirkan kebudayaan, mengubah benda-benda alam menjadi benda-benda budaya sesuai dengan kehendak dan kebutuhan hidupnya, karena akal juga manusia menjadi makhluk yang memiliki daya cipta yang tinggi,

\footnotetext{
${ }^{12}$ Syahidin, Metode Pendidikan Qur'an Teori dan Aplikasi, (Jakarta: Misada Balita, 2001), h. 28-33.

${ }^{13}$ Ali Al Hamady, Jalan Hidup Muslim, (Bandung: PT. Al-Ma'arif, 1994), h. 18.
}

Jurnal Ilmiah Al QALAM, Vol. 12, No. 2, Juli-Desember 2018 
Mohamad Nursalim Azmi dan Muhammad Zulkifli: Manusia, Akal dan Kebahagiaan (Studi Analisis Komparatif antara Alquran dengan Filsafat)

sehingga manusia menjadi makhluk bijaksana yang mencari tujuan hidupnya ${ }^{14}$.

Tentang pemberian akal Allah telah menerangkan dalam firmannya surat an-Nahl ayat 78 :

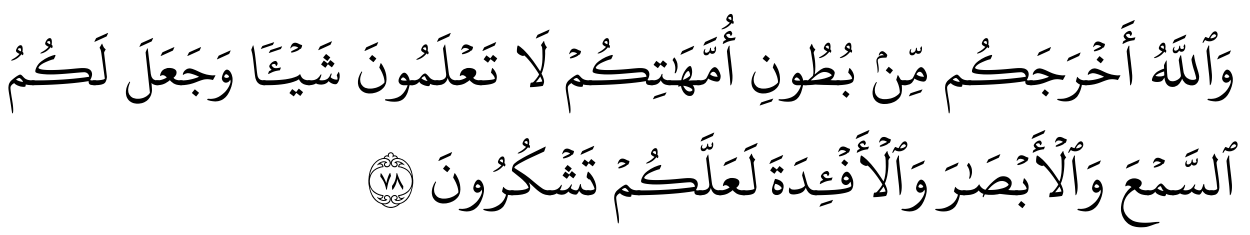

Artinya : Dan Allah mengeluarkan kamu dari perut ibumu dalam Keadaan tidak mengetahui sesuatupun, dan Dia memberi kamu pendengaran, penglihatan dan hati, agar kamu bersyukur.

Oleh karena itulah, sering benar Allah SWT menyuruh manusia berpikir atau menggunakan akal supaya cerdas dan berbuahkan manfaat yang baik dan berguna bagi diri sendiri dan bagi umum. Karena akal yang tidak digunakan untuk berpikir, niscaya mudah rusak dan tidak berguna apa-apa.

Setiap orang menyadari bahwa ia mempunyai akal, akal berpusat di otak, hasil rumusan akal (pikiran) dapat dirasakan dan diyakini kebenarannya, hasil kerja akal dapat memberikan rasa kenikmatan tersendiri pada diri individu. Penggunaan akal dapat menentukan kedudukan seseorang dalam lingkungan sosialnya, dapat membuat dia senang atau marah. Kemampuan akal merupakan nikmat Tuhan yang paling besarndan ini pulalah yang membuat manusia itu istimewa dan mulia dibandingkan dengan makhluk lainnya. 1994), h. 75.

${ }^{14}$ Djumberansyah Indar, Filsafat Pendidikan, (Surabaya: Karya Abditama, Jurnal Ilmiah Al QALAM, Vol. 12, No. 2, Juli-Desember 2018 
Mohamad Nursalim Azmi dan Muhammad Zulkifli: Manusia, Akal dan Kebahagiaan (Studi Analisis Komparatif antara Alquran dengan Filsafat)

Perbedaaan menyeluruh antara manusia dengan binatang ialah manusia dikaruniai akal oleh Allah SWT. Maka dalam ilmu mantiq (logika) manusia dirumuskan dengan hayawanun natiq (hewan yang berpikir/berbicara). Dengan akal pikiran itulah melahirkan laku perbuatan yang dikerjakan sehari-hari dalam rangka hubungan dengan manusia lain ${ }^{15}$. Allah SWT menyuruh manusia menggunakan akal atau kemampuan berpikir ini sebaik-baiknya, baik berpikir tentang dirinya sendiri atau tentang alam semesta.

Sebagai makhluk berakal, manusia mengamati sesuatu. Hasil pengaatan itu diolah menjadi ilmu pengetahuan. Dengan ilmu pengetahuan itu dirumuskan ilmu baru yang akan dipergunakannya dalam usaha memenuhi kebutuhan hidupnya dan menjangkau jauh ke luar kemampuan fisiknya. Demikian banyak hasil kemajuan ilmu pengetahuan yang membuat manusia dapat hidup menguasai alam ini.

Lebih jauh lagi, dalam Alquran juga diuraikan tentang pentingnya berpikir dalam kehidupan manusia. Juga ditinggalkannya nilai manusia yang mempergunakan akal budi dan pemikirannya, dan direndahkannya martabat manusia yang tidak mempergunakan akal budi dan pemikirannya dan menjadikannya lebih rendah dari padapada hewan. Allah SWT berfirman dalam surat Al-Anfal ayat 22 yang berbunyi :

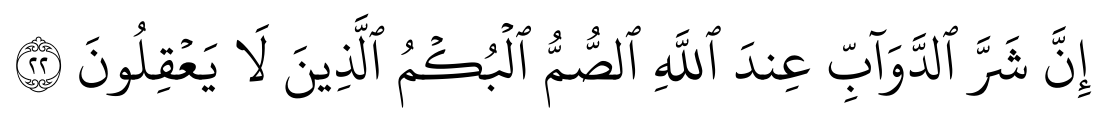

Artinya : Sesungguhnya binatang (makhluk) yang seburuk-buruknya pada sisi Allah ialah; orang-orang yang pekak dan tuli yang tidak mengerti apa-apapun.

${ }^{15}$ Nasruddin Razak, Denul Islam (Bandung: PT. Al-Ma'arif, 1971), h. 15.

Jurnal Ilmiah Al QALAM, Vol. 12, No. 2, Juli-Desember 2018 
Mohamad Nursalim Azmi dan Muhammad Zulkifli: Manusia, Akal dan Kebahagiaan (Studi Analisis Komparatif antara Alquran dengan Filsafat)

Secara fisik manusia lebih lemah daripada hewan, oleh karena itu manusia dengan akalnya menciptakan peralatan untuk mempertahankan diri dan kehidupannya. Sebaliknya hewan secara fisik lebih kuat, dan dilengkapi dengan alat yang merupakan senjata, seperti ayam jago dengan tajinya, binatang buas dengan kuku tajam dan taringnya, ular dengan bisanya, gajah dengan fisiknya yang kuat. Namun hewan tidak mampu membuat peralatan, sehingga bagaimanapun lemahnya manusia, dengan akalnya masih bisa menguasai mereka itu ${ }^{16}$.

Jadi betul kata banyak orang, faktor terbesar yang membuat manusia itu mulia adalah karena ia berakal. Ia dapat hidup senang dan tentram karena memiliki akal, dengan akal manusia dapat memperoleh ilmu pengetahuan, dan dengan ilmu pengetahuan ia dapat menguasai alam ini. Inilah rupanya pandangan filsafat Islam tentang akal yang diberikan Allah SWT kepada manusia, yaitu untuk mengangkat harkat dan martabat hidupnya, untuk mempertahankan dirinya dan untuk menjalankan fungsi sebagai 'abd dan khalifah Allah SWT.

\section{c. Pandangan Filsafat Islam Terhadap Kebahagiaan}

Kebahagian berasal dari kata bahagia yang berarti perasaan senang, atau keadaan/perasaan senang, tentram (bebas dari segala yang menyusahkan, kebahagiaan ialah perasaan bahagia, kesenangan dan ketentraman hidup (lahir dan batin) ${ }^{17}$.

Ahli Filsafat dan Tasawuf berselisih faham dari susunan bahagia itu, artinya berapakah pencampuran zat yang kelak menjadi zat yang tersendiri yaitu bahagia? Ibarat ilmu kimia, berapakah zat kapur, vitamin, zat putih telur dan lain-lain yang diaduk menjadi tubuh bahagia.

\footnotetext{
${ }^{16}$ Rohiman Notowidagdo, Ilmu Budaya Dasar ...., h. 26.

${ }^{17}$ Tim Redaksi, Kamus Besar Bahasa Indonesia..., h. 75.
}

Jurnal Ilmiah Al QALAM, Vol. 12, No. 2, Juli-Desember 2018 
Mohamad Nursalim Azmi dan Muhammad Zulkifli: Manusia, Akal dan Kebahagiaan (Studi Analisis Komparatif antara Alquran dengan Filsafat)

Golongan pertama dari kelompok filsafat, yang diwakili oleh Aristoteles, mengemukakan ada 5 (lima) perkara anasir bahagia, yaitu :

1. Badan sehat, panca indera cukup (memadai pendengaran, pengkihatan, penciuman, perasaan lidah dan perasaan kulit.

2. Cukup kekayaan, sehingga sanggup meletakkan harta pada keperluannya di dalam mencapai kebaikan.

3. Indah sebutan diantara manusia, terpuji dimana-mana.

4. Tercapai apa yang dicita-citakan di dalam mengarungi lautan hidup.

5. Tajam pikiran, runcing pendapatan, sempurna dalam beragama dan terjauh dari kesalahan ${ }^{18}$.

Bila terkumpul semuanya itu, tercapailah bahagia yang sempurna, demikian pendapat Aristoteles.

Kelompok pertama ini berpendapat, badan itu setu bagian dari manusia. Bukan satu perkakas, sebab itu mereka berkeyakinan bahwa kebahagiaan jiwa tidak akan sempurna jika tidak tercapai lebih dahulu kebahagiaan badan kasar. Demikian juga kebahagiaan yang datang dari luar badan, yaitu segala mata benda dan kemuliaan yang di dapat dengan bersungguh-sungguh. Untuk mencapai bahagia yang cukup, orang perlu mempunyai indera yang lengkap, perasaan yang halus, dan tajam pikiran.

Kelompok kedua dari kaum Tasawuf, mereka berpendapat bahwa segala keutamaan dan bahagia itu hanya dirasakan oleh diri dan oleh nafsu. Oleh sebab itu ketika mereka membagi-bagi anasir bahagia, semua mereka taklukan kepada kekuatan kedirian semata, yaitu hikmah, keberanian, keteguhan dan keadilan.

\footnotetext{
${ }^{18}$ Hamka, Tasawuf Modern, (Jakarta: Pustaka Panjimas, 1970), h. 37.

Jurnal Ilmiah Al QALAM, Vol. 12, No. 2, Juli-Desember 2018
} 
Mohamad Nursalim Azmi dan Muhammad Zulkifli: Manusia, Akal dan Kebahagiaan (Studi Analisis Komparatif antara Alquran dengan Filsafat)

Mereka setuju bahwa barang siapa yang terkumpul padanya sifatsifat yang 4 (empat) itu, tidaklah perlu lagi mempunyai sifat yang lain. Sebab sifat-sifat yang lain itu sebagai ranting saja, semuanya berhubungan dengan dahan-dahan besar yang empat perkara itu. Kesuburan pokok dengan sendirinya akan menumbuhkan banyak dahan dan ranting. Tidak perlu kepada sifat-sifat yang timbul dari luar diri.

Jika keempat sifat itu telah terkumpul pada manusia, maka kebahagiaannya tidak akan kurang atau cacat lantaran kerusakan atau kekurangan yang ada pada tubuh kasarnya, sebab keempat sifat itu tadi bukan jasmani, tetapi sifat rohani. Tetapi jika dia beroleh penyakit mengenai rohani seperti gila, lemah otak dan lain-lain, maka cacatlah bahagianya. Juga tidak mengurangi bahagia, jika ia ditimpa kecelakaan yang datang dari luar badanya, misalnya miskin papa, jatuh perniagaan, tidak lah akan mengurangi kebahagiaannya, kalau rohani yang empat tadi telah ada padanya ${ }^{19}$.

Imam Ghazali mengatakan, disini sangat relatif artinya, tidak ada batasan yang jelas, terutama tentang bagaimana dan kapan seseorang mencapai sesuatu nikmat. Beliau menjelaskan sesungguhnya kebahagiaan itu adalah tujuan hidup manusia, bahagia di dunia dan bahagia di akhirat. Berbahagia di dunia itulah yang relatif, yang mungkin berbeda antara yang satu dengan yang lainnya. Lain hal dengan bahagia di akhirat, jelas bentuknya yaitu surga dan segala kenikmatannya yang berpuncak saat manusia melihat Tuhan.

Jalan menuju bahagia boleh sukar, tetapi boleh pula mudah. Mana jalan yang pendek dan mudah? Jalan itu ialah agama. Bukan lantaran agama itu melarang orang berpikir, bahkan agamalah yang membuka

\footnotetext{
${ }^{19}$ Hamka, Tasawuf Modern ...., hal. 38.
}

Jurnal Ilmiah Al QALAM, Vol. 12, No. 2, Juli-Desember 2018 
Mohamad Nursalim Azmi dan Muhammad Zulkifli: Manusia, Akal dan Kebahagiaan (Studi Analisis Komparatif antara Alquran dengan Filsafat)

pintu pikiran, menyuruh menjalankan akal dan pendapat di dalam segala perkara, dari alam dan dan hal manusia, bekas nikmat dan anugerah kekuasaan yang ghaib, maksud agama ialah merentangkan jalan, sedang pikiran ialah untuk membanding dan menimbang. Segala tujuan itu terkumpul dalam agama dan agama tidak terorganisikan selain dengan terorganisasinya dunia. Dunia adalah tempat bercocok tanam bagi akhirat. Dunia adalah alat yang menyampaikan kepada Allah SWT bagi orang yang mau memperbuatnya menjadi tempat tetap dan tanah air $\operatorname{abadi}^{20}$.

Selanjutnya al-Ghazali menjelaskan bahwa manusia untuk mencapai kebahagiaan harus melalui tiga tahapan, yaitu : pengetahuan (ilmu), keadaan tertentu di dalam pribadi (hal seseorang) dan amal (tindakan). Manusia tidak akan mencapai tujuan hidupnya kecuali melalui ilmu dan amal. Dan ia tidak akan dapat beramal kecuali dengan mengetahui cara pelaksanaan amal, dengan demikian pangkal kebagahiaan dunia dan akhirat, sebagai tujuan hidup adalah ilmu ${ }^{21}$.

Ilmu diperoleh dengan memperdayagunakan akal dan pikiran, bertambah luas akal, bertambah luas hidupnya, bertambah datanglah bahagia, bertambah sempit akal, bertambah sempit pula hidup, dan bertambah datanglah celaka.

\footnotetext{
${ }^{20}$ Abidin Ibnu Rusn, Pemikiran Al-Ghazali Tentang Pendidikan (Yogyakarta: Pustaka Pelajar, 1988), h. 37.

${ }^{21}$ Abidin Ibnu Rusn, Pemikiran Al-Ghazali ...., hal. 38.

Jurnal Ilmiah Al QALAM, Vol. 12, No. 2, Juli-Desember 2018 
Mohamad Nursalim Azmi dan Muhammad Zulkifli: Manusia, Akal dan Kebahagiaan (Studi Analisis Komparatif antara Alquran dengan Filsafat)

Allah SWT berfirman :

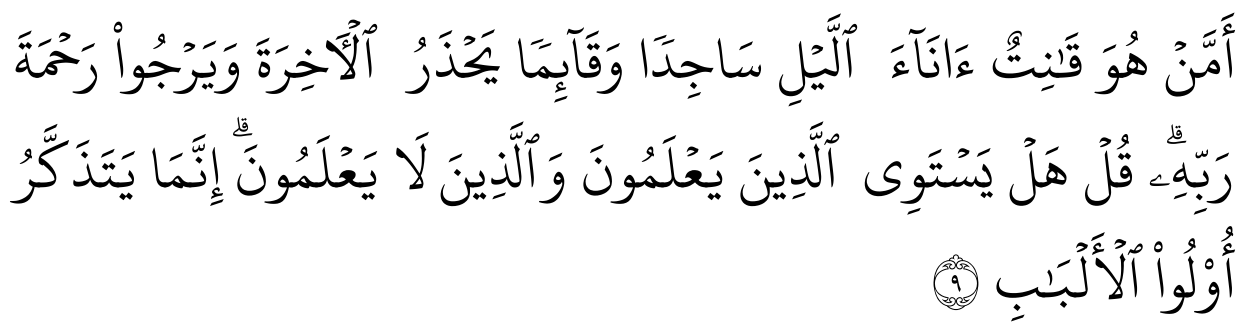

Artinya : (apakah kamu Hai orang musyrik yang lebih beruntung) ataukah orang yang beribadat di waktu-waktu malam dengan sujud dan berdiri, sedang ia takut kepada (azab) akhirat dan mengharapkan rahmat Tuhannya? Katakanlah: "Adakah sama orang-orang yang mengetahui dengan orang-orang yang tidak mengetahui?" Sesungguhnya orang yang berakallah yang dapat menerima pelajaran. (QS. Az-zumar : 9).

Allah SWT berfirman :

Rasulullah SAW bersabda :

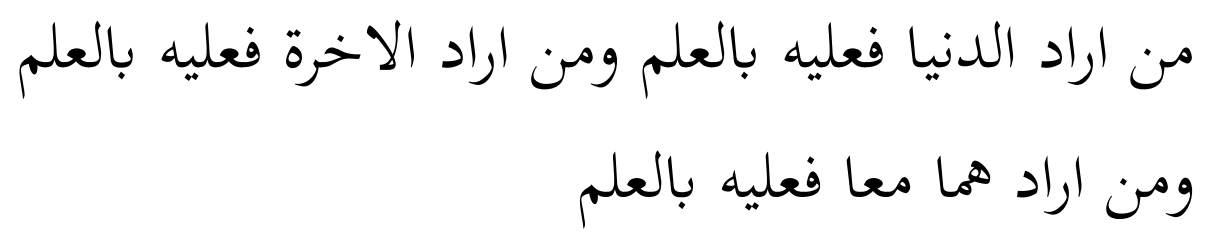

Artinya : Siapa yang ingin dunia (hidup di dunia dengan baik), hendaklah ia berilmu, siapa yang akhirat (hidup di akhirat nanti dengan senang) hendaklah ia berilmu, siapa yang ingin keduanya, hendaklah ia berilmu. (HR. Imam Ahmad).

\section{Simpulan}

Manusia pada pandangan Islam adalah makhluk Allah SWT, makhluk yang diciptakan oleh Allah SWT. Manusia tidak sama dengan hewan dan tidak sama pula dengan malaikat. Manusia adalah makhluk dua dimensional, yang terdiri dari unsur jasmani dan rohani, dan pandangan Islam manusia itu juga terletak pada amal dan karyanya. 
Mohamad Nursalim Azmi dan Muhammad Zulkifli: Manusia, Akal dan Kebahagiaan (Studi Analisis Komparatif antara Alquran dengan Filsafat)

Kelebihan manusia dibandingkan dengan hewan terletak pada unsur rohaninya, terutama pada akalnya, akal diberikan Allah SWT kepada manusia tetapi tidak kepada hewan. Akal adalah anugerah yang terbesar dan amat berharga. Dengan akal manusia dapat mengarungi lautan dunia yang fana ini, yang akhirnya dengan akal pulalah manusia mampu meraih kebahagiaan (sebagai tujuan hidupnya), bahagia di dunia dan bahagia di akhirat.

Jurnal Ilmiah Al QALAM, Vol. 12, No. 2, Juli-Desember 2018 
Mohamad Nursalim Azmi dan Muhammad Zulkifli: Manusia, Akal dan Kebahagiaan (Studi Analisis Komparatif antara Alquran dengan Filsafat)

\section{Daftar Pustaka}

Bucaille, Mauries. Asul-usul Manusia Menurut Bibel, Alquran dan Sains, Mizan, Bandung, 1989.

Departemen Agama RI, Alquran dan Terjemahnya Ar-Raafi', CV. Madinatul Ilmi, Jakarta, 2012.

Faruq, Ismail Raji. Islam dan Kebudayaan, Mizan, Bandung, 1984.

Halim, Abdul (editor), Teologi Islam Rasional, Ciputat Press, Jakarta, 2002.

Hamady, Ali. Jalan Hidup Muslim, PT. Al-Ma'arif, Bandung, 1994.

Hamka. Tasawuf Modern, Pustaka Panjimas, Jakarta, 1970.

Haryanto, Agung Tri dan Eko Sujatmiko, Kamus Sosiologi, Aksarra Sinergi Media, Surakarta, 2012.

Indar, Djumberansyah Indar. Filsafat Pendidikan, Karya Abditama, Surabaya, 1994.

Najati, M.Ustman. Alquran dan Ilmu Jiwa, Pustaka, Bandung, 1985.

Nizar, Samsul Nizar. Filsafat Pendidikan Islam, Ciputat Press, Jakarta, 2002.

Notowidagdo, Rohiman. Ilmu Budaya Dasar Alquran dan Hadits, PT. Raja Grafindo Persada, Jakarta, 1996.

P.P.Grasse, L'Homme Accusation (Manusia sebagai Tertuduh), dikutib DR. Mauries Bucaille, dalam asal-usul Manusia menurut Bibel, Alquran dan Sains, Mizan, Bandung, 1989.

Razak, Nasruddin. Denul Islam, PT. Al-Ma'arif, Bandung, 1971.

Rusn, Abidin Ibnu. Pemikiran Al-Ghazali Tentang Pendidikan, Pustaka Pelajar, Yogyakarta, 1988.

Syahidin. Metode Pendidikan Qur'an Teori dan Aplikasi, Misada Balita, Jakarta, 2001.

Tim Redaksi. Kamus Besar Bahasa Indonesia, Edisi Kedua, Balai Pustaka, Jakarta, 1991.

Zuhairini dkk. Filsafat Pendidikan Islam, Bumi Aksara, Jakarta, 1992.

Jurnal Ilmiah Al QALAM, Vol. 12, No. 2, Juli-Desember 2018 